Araștırma Makalesi $\begin{array}{ll}\text { Geliș/Received } & : 10.08 .2020 \\ \text { Kabul/Accepted } & : 30.09 .2020\end{array}$

DOI: 10.47793/hp.778913

\title{
Genç Yetişkinlerde Duygusal Zeka, Empati ve Sosyal Beceri Düzeyi Arası İlişkilerin İncelenmesi
}

\section{ÖZET}

Bu çalş̧̧mada genç yetişkinlerde duygusal zeka, empati ve sosyal beceri düzeyi arasındaki ilişsilerin incelenmesi amaçlanmıştır. Çalışmaya 18-39 yaş arasında 169 kadın ve 150 erkek olmak üzere toplam 319 kişi katılmıştır. Katılımcılar A Sosyal Beceri Ölçeği-80, Empati Ölçeği ve Asıl Form Schutte Duygusal Zeka Testi’ni cevaplamıştır. Çalışmada duygusal zeka, empati ve sosyal beceri arası ilişkiler farklı modeller ile incelenmiştir. Bu doğrultuda ele alınan değişkenler arasındaki ilişkileri açıklamaya yönelik yedi model oluşturulmuştur. Oluşturulan modeller yol analizi ile incelenmiş ve farklı düzeylerde uyum gösterdikleri belirlenmiştir. Sosyal beceri ile duygusal zeka arasındaki ilişkide empatinin aracı rolünü gösteren model belirtilen modeller içerisinde en iyi uyum gösterge değerleri veren model olarak yer almıştır. Değişkenler arası ilişkiler için elde edilen sonuçlar, yakın geçmişteki ilgili çalışma sonuçları doğrultusunda tartışılmıştır.

Anahtar Kelimeler: duygusal empati, bilissel empati, duygusal zeka, sosyal beceri, empati

\section{Investigation of the Relations between Emotional Intelligence, Empathy and Social Skill Level in Young Adults}

\begin{abstract}
It was aimed to investigate the relationships between emotional intelligence, empathy and social skill level in young adults in this study. Total numbers of participated in the study including 169 women and 150 men aged between 18-39 are 319. Participants answered the A Social Skill Test-80, Empathy Scale and original form of Schutte Emotional Intelligence Test. In this study was investigated the relationships between emotional intelligence, empathy and social skills with different models. In this direction, seven models were created to explain the relationships between the variables. The created models were investigated by path analysis and determined that they showed different levels of compliance. It is the best fit indicator among the were used models that showed model the mediating role of empathy in the relationship between the social skill and emotional intelligence. The results obtained for the relationships between variables are discussed in line with the recent study results.
\end{abstract} Keywords: emotional empathy, cognitive empathy, emotional intelligence, social skill, empathy 
Ekim 2020, Cilt 2, Sayı 3

October 2020, Volume 2, Issue 3
İletișim / Contact

Mail : info@humanisticperspective.com Web : https://dergipark.org.tr/tr/pub/hp

\section{GİRİŞ}

$\mathrm{H}$ erhangi bir olaya tepki olarak ortaya çıkan ve nesne ile kurulan ilişki biçimine göre çeşitlilik gösteren duygular, kişinin düşünce, davranış ve yönelimlerine rehberlik etmektedir. Bu sebeple duygusal beceriler, sosyal çevre ile etkileşimde önemli hale gelmektedir (Lopes, Brackett, Nezlek, Schütz, Sellin ve Salovey, 2004). Duygusal uyaranlar1 alg1lama ve duygusal bilgiyi işleme süreci olarak kabul edilen duygusal zeka, kişiden kişiye farklılık göstermektedir (Mayer, Salovey, Caruso, 2008). Duygusal zeka bir kısım araştırmacı tarafindan yetenek olarak kabul edilirken, diğerleri duygusal zekanın ayırt edici bir kişilik özelliği (trait) olduğunu ileri sürmektedir. "Karma model" olarak da adlandırılan kişilik yaklaşımı, kişinin kendi duyguları$\mathrm{n}$ algılamasını, empati yoluyla başkasının duygularını anlamasını ve duygusal bilgileri düşünce ve davranışlarına yön vermede kullanmasını kişiliğin bir parçası olarak değerlendirmektedir (Sharma, Deller, Biswal, Mandal, 2009; Tatar, Saltukoğlu, Tok ve Bender, 2016). "Yetenek modeli” ise duygusal zekayı standart zeka bölümlerinden biri olarak değerlendirmektedir. Bu model, duygusal bilgi işleme süreçlerine odaklanarak dört kategoride incelemektedir (Mayer, Caruso ve Salovey, 2016).

Her iki modelin de kişilerarası ilişkilerde empatiyi ön plana çıkarması, empati becerisinin duygusal zeka için kritik öneme sahip olduğunu göstermektedir (Petrovici ve Dobrescu, 2014; Stanley ve Bhuvaneswari, 2016). Diğer yandan empatinin ise bilişsel ve duygusal olmak üzere iki bileşenden oluştuğu ileri sürülmektedir. Bilişsel empati, başkalarının ruh halini imgesel olarak anlamayı ifade ederken, duygusal empati başkalarının duygusal mesajlarına duygusal olarak karşıllık vermeyi gerektirmektedir (Lawrence, Shaw, Baker, Baron-Cohen ve David, 2004). Empati düzeyini ve bireysel farklılıkları ölçmek üzere geliştirilen ölçek çalışmaları da empatinin tek bir yapıdan oluşmadığını, birden çok bileşeni olduğunu doğrulamaktadır. Bilişsel empati ve duygusal tepkiselliğin (emotional reactivity) yanı sıra sosyal beceri de empati kapsamında değerlendirilmektedir (Davis, 1983; Muncer ve Ling, 2006).

Sosyal beceri ile empatinin alt boyutları arasında paralellik olduğu, her iki yapının da birbiriyle kişiler arası iletişimi başlatma ve sürdürme için gereken beceriler açısından örtüştüğü belirtilmektedir (Riggio, Tucker ve Coffaro, 1989). Bu bağlamda, sağlıklı bir empatik iletişim için duyarlılık, duyguları okuma/anlama, duyguları ifade edebilme gibi sosyal beceriler gerekli görülürken, diğer taraftan empati yapabilme yeteneği de sosyal beceri göstergelerinden biri olarak kabul edilmektedir. Kişinin başkalarının duygu ve düşüncelerini anlayabilmesi ve farklı bakış açıları kazanabilmesi için, çevreye karşı duyarlı olması, sözel ve sözel olmayan iletişim becerilerine sahip olması, duruma özgü davranışlar sergileyerek ilişkileri yönetebilmesi ve kontrollü, sosyal bir aktör olabilmesi gerekmektedir. Sağlıklı kişilerarası ilişkilerin yürütülebilmesi için kişinin sosyal ortamda kendinin farkında olması, empati kurabilmesi, iş birliği yapabilmesi gibi çeşitli sosyal becerilere sahip olması gerektiği belirtilmektedir (Schutte ve ark., 2001). Diğer yandan da duygu, düşünce ve isteklerin açık bir şekilde ifade edilmesi, empati yapılması ve kendi hakkını ararken başkalarının haklarına da saygı duyulmasının kişilerarası ilişki problemlerini azalttı̆̆ı ortaya konulmuştur (Garaigordobil ve Peña, 2014; Khodabakhsh ve Besharat, 2011).

Bilgi alış-verişine dayalı sosyal beceriler çok boyutlu yapıda ele alınırken, a) duygusal dışavu- 
rum, b) duygusal duyarlilık, c) duygusal denetim, d) sosyal dışavurum, e) sosyal duyarlılık, f) sosyal denetim ve g) sosyal manipülasyon olmak üzere duyarlılık ve ifade etme temelinde yedi kategorisi tanımlanmaktadır. Bu yaklaşımda kişinin kendi duyguları ile olan etkileşimi ve empati becerisi öncelikli öneme sahiptir ve bu beceri boyutları duygusal zeka bileşenleriyle örtüşüyor gibi görünmektedir. Özellikle olgusal olarak empati, duygusal zeka ile sosyal beceri arasındaki ilişkiyi ortaya koymada kritik öneme sahiptir (Riggio, 1986).

Duygusal zeka, empati ve sosyal beceri üzerine yürütülen çalışmalar ayrı ayrı, sosyal beceri ile empati arasındaki ilişkiyi (Ishak, Abidin ve Bakar, 2014; Riggio ve ark., 1989; Zorza, Marino, de Lemus ve Mesas, 2013), duygusal zeka ile empati arasındaki ilişkiyi (Clarke, Marks ve Lykins, 2016; Kaelber ve Schwartz, 2014; Stanley ve Bhuvaneswari, 2016) ve sosyal beceri ile duygusal zeka arasindaki ilişkiyi (Lopes ve ark., 2004; Mustaffa, Nasir, Aziz ve Mahmood, 2013; Schutte, Malouff, Bobik, Coston, Greeson, Jedlicka, Rhodes ve Wendorf 2001; Yip ve Martin, 2006) ortaya koymaktadir. Belirtilen bu araştırmalardan elde edilen bulgular, yüksek duygusal zekaya sahip bireylerin sosyal beceri ve empati düzeylerinin de yüksek olduğunu göstermektedir (Castillo, Salguero, FernándezBerrocal ve Balluerka, 2013; Mayer, Carusso ve Salovey, 1999; Schutte ve ark., 2001). Diğer taraftan sosyal beceri (Adams, 1983; Denton ve Zarbatany, 1996; Flynn, Ricker, Dolezal, Kunin ve Mellins, 2019; Zhaoyang, Sliwinski, Martire ve Smyth, 2018) empati (Adams, Schvaneveldt ve Jensen, 1979; Richter ve Kunzmann, 2011; Wieck ve Kunzmann, 2015) ve duygusal zekanın (Cabello ve ark., 2016; Mayer ve ark., 2016) yaşa bağlı olarak değişim gösterdiği ilgili çalışmalarda belirtilmektedir.

Farklı yaş grupları için ele alınan olgular arası ilişkilerin farklı çalışmalarla ayrı ayrı incelenmesi gerektiği anlaşılmaktadır. Bu çalışmada ise genç yetişkin olarak tanımlanan çerçevede (Shaffer ve Kipp, 2010) katılımcı yaş grubu belirlenmiş, belirtilenlerin yol (path) analiziyle bu grup üzerinde test edilmesinin yanı sıra bu üç olgunun birlikte ele alınmasıyla ortaya konulacak ilişkisel yapının daha fazla bilgi sağlayabileceği düşünülmüştür. Bu belirtilenler doğrultusunda bu çalışmada duygusal zeka, empati ve sosyal beceri düzeyi arasındaki ilişkilerin yol analiziyle incelenmesi amaçlanmıştır.

\section{YÖNTEM}

\section{Çalışma Grubu}

Çalışmaya kolay örnekleme yöntemiyle ulaşılan, 18-39 yaş arasında (ort. $=24,19 ; \mathrm{s}=5,62$ ) 169 kadın (\%53,0), 150 erkek (\%47,0) toplam 319 kişi katılmıştır. Katılımcıların gelir durumlarının, 11 kişinin $(\% 3,4)$ düşük, 192 kişinin $(\% 60,2)$ orta ve 114 kişinin $(\% 35,7)$ yüksek düzey olduğu (2 kişi $(\% 0,6)$ gelir durumunu belirtmemiştir) belirlenmiştir.

\section{Veri Toplama Araçları}

Çalışmada yetişkinler için A Sosyal Beceri Ölçeği-80, Empati Ölçeği uzun formu, Asıl Form Schutte Duygusal Zeka Testi kullanılmıştır.

A Sosyal Beceri Ölçeği-80: Ölçek, 5'li Likert tipi cevaplama seçeneği içeren (1 = Hiçbir Zaman, 5 = Her Zaman) 80 maddeden oluşmaktadır ve sosyal beceriyi tek boyutlu yapıla değerlendirmektedir. Ölçekten alınan yüksek puan, sosyal becerinin yüksek oluşuna işaret etmektedir. Öl- 
iletișim / Contact

Mail : info@humanisticperspective.com Web : https://dergipark.org.tr/tr/pub/hp

çeğin geliştirildiği çalışmada iç tutarlılık güvenirlik katsayısı, tüm grup, kadın grubu ve erkek grubu için 0,96, test-tekrar test güvenirlik katsayısı 0,70 olarak bildirilmiştir (Tatar ve ark., 2018).

Empati Ölçeği: Empatinin ölçülmesi amacıyla geliştirilmiş olan Empati Ölçeği uzun formu (Baron-Cohen ve Wheelwright, 2004) Türkçe'ye çevirisi Bora ve Baysan (2009) tarafından yürütülmüştür. Ölçek uzun formu 60 maddeli ve 40 maddesi ile (20 maddesi dolgu maddesi olarak değerlendirilme dışı tutulmaktadır) değerlendirilen 0-80 arasında puan üreten bir ölçme aracıdır. Altı tanesi ters yönlü olarak puanlanan ölçek maddeleri dört cevap seçeneği içermesine ("kesinlikle katıliyorum" ve "kesinlikle katılmıyorum" arasında) karşın en az empatik iki yanıt seçeneği 0, orta düzeyde empatik yanıt seçeneği 1 ve en empatik yanıt seçeneği 2 puanla değerlendirilmektedir. Ölçekten alınan yüksek puanlar empati kurabilme yeteneğinin yüksekliğine işaret etmektedir. Ölçeğin Türkçe çeviri çalışmasında iç tutarlılık güvenirlik katsayısı 0,85 , test-tekrar test güvenirlik katsayısı 0,76 olarak belirtilmiştir (Baron-Cohen ve Wheelwright, 2004; Bora ve Baysan, 2009).

Asıl Form Schutte Duygusal Zeka Testi: Duygusal zekanın tek boyutlu değerlendirilmesi amacıyla geliştirilen test 5'li Likert tipi cevaplama seçeneği içeren (1 = Kesinlikle Katılmıyorum, 5 = Kesinlikle Kat1liyorum) 33 maddeden oluşmaktadır (Schutte, ve ark., 1998). Üç maddesi ters yönlü olarak puanlanan testin Türkçe çeviri çalışmasında iç tutarlılık katsayısı 0,86, 15 gün ve 30 gün arayla yürütülen iki ayrı test-tekrar test güvenirlik katsayıları da sırasıyla 0,81 ve 0,78 olarak belirtilmiştir (Tatar, Tok, Bender ve Saltukoğlu, 2017).

\section{Uygulama}

Çalışma, altı aylık süre içerisinde kolay örnekleme yöntemiyle İstanbul ilinde araştırmacılar tarafindan ulaşılan kişilerle yüz yüze uygulama ile bireysel olarak gerçekleştirilmiştir. Çalışma, kağıt-kalem formlarının katılımcılar tarafından öz bildirim yoluyla cevaplamasıyla yürütülmüş ve bir kişilik uygulama yaklaşık yarım saat sürmüştür.

\section{BULGULAR}

Çalışmada öncelikle kullanılan ölçme araçlarının iç tutarlılık güvenirlik katsayıları ve toplam puanları arası korelasyon katsayıları hesaplanmıştır. İç tutarlılık güvenirlik katsayıları A Sosyal Beceri Ölçeği-80 için 0,94, Empati Ölçeği için 0,85 ve Asıl Form Schutte Duygusal Zeka Testi için 0,93 olarak hesaplanmıştır. Toplam puanları arası korelasyon katsayıları ise A Sosyal Beceri Ölçeği-80 ile Empati Ölçeği arasında 0,64, Asıl Form Schutte ile Duygusal Zeka Testi arasında 0,47; Empati Ölçeği ile Asıl Form Schutte Duygusal Zeka Testi arasında ise 0,48 olarak hesaplanmıştır (Tablo 1). 
Tablo 1. Kullanılan Ölçme Araçlarının İç Tutarlılık Güvenirlik Katsayıları ve Toplam Puanları Aras1 Korelasyon Katsay1lar1

\begin{tabular}{lcccc}
\hline & $\mathbf{k}$ & Alfa & $\mathbf{1}$ & $\mathbf{2}$ \\
\hline 1. A Sosyal Beceri Ölçeği-80 & 80 & 0,94 & & \\
2. Empati Ölçeği & 40 & 0,85 & $0,64^{* * *}$ & \\
3. Assl Form Schutte Duygusal Zeka Testi & 33 & 0,93 & $0,47^{* * *}$ & $0,48^{* * *}$ \\
\hline
\end{tabular}
$* * * \mathrm{p}<0,001$

Çalışmada daha sonra yapılan işlem ise yol analizi ile duygusal zeka, empati ve sosyal beceri arası ilişkilerin farklı modellerle incelenmesi olmuştur. Çalışmada üç olgu için ele alınan değişik ilişkisel yapılar oluşturulmuş ve bunlar test edilmiştir. Kurulan modeller, üç olgusal yapı arasındaki olası seçenekleri yansıtacak şekilde oluşturulmuştur. Ele alınan değişkenler arası ilişkileri açıklamaya yönelik olarak yedi model oluşturulmuş ve test edilmiştir.

Bu modeller:

a) Sosyal becerinin ve empatinin duygusal zekay1 etkilediği (Clarke ve ark., 2016; Kaelber ve Schwartz, 2014; Stanley ve Bhuvaneswari, 2016) (Model 1)

b) Sosyal becerinin duygusal zekayı, duygusal zekanın da empatiyi etkilediği (Castillo ve ark., 2013; Mayer ve ark., 1999; Schutte ve ark., 2001) (Model 2)

c) Duygusal zeka ve empatinin sosyal beceriyi etkilediği (Lopes ve ark., 2004; Mustaffa ve ark., 2013; Schutte ve ark., 2001; Yip ve Martin, 2006) (Model 3)

d) Duygusal zeka ve sosyal becerinin empatiyi etkilediği (Ishak ve ark., 2014; Riggio ve ark., 1989; Zorza ve ark., 2013) (Model 4)

e) Sosyal becerinin hem empatiyi hem duygusal zekayı, empatinin de duygusal zekayı etkilediği (Castillo ve ark., 2013; Mayer ve ark., 1999; Schutte ve ark., 2001) (Model 5)

f) Duygusal zekanın sosyal beceriyi, sosyal becerinin de empatiyi etkilediği (Castillo ve ark., 2013; Mayer ve ark., 1999; Schutte ve ark., 2001) (Model 6)

g) Sosyal becerinin empatiyi, empatinin de duygusal zekay1 etkilediği (Riggio, 1986) (Model 7)

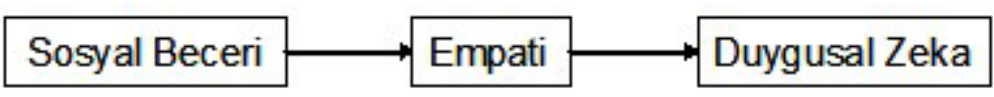

Şekil 1. Sosyal Beceri, Empati, Duygusal Zeka İlişkisi (Model 7)

Empatinin, sosyal beceri ve duygusal zeka arasında aracı değişken olarak ele alındığı Model 7'nin şekilsel gösterimine Şekil 1'de yer verilmiştir. Bu ve diğer modellerin uyum iyiliği gösterge değerleri hesaplanarak Tablo 2'de gösterilmiştir. Modellerin genel olarak uyum iyiliği gösterge değerleri düşük değerlerden yüksek değerlere olacak şekilde sıralanarak tabloda yer verilmiştir. 
Ekim 2020, Cilt 2, Sayı 3

October 2020, Volume 2, Issue 3
İletișim / Contact

Mail : info@humanisticperspective.com Web : https://dergipark.org.tr/tr/pub/hp

Tablo 2. Farklı Modeller İçin Doğrulayıcı Faktör Analizi Uyum İyiliği İstatistikleri

\begin{tabular}{|c|c|c|c|c|c|c|c|c|}
\hline Modeller & Ki-kare & sd & $\begin{array}{l}\text { Ki- } \\
\text { Kare / } \\
\text { sd }\end{array}$ & $\begin{array}{c}\text { Iyi } \\
\text { Uyum } \\
\text { İndeksi } \\
(\mathrm{GFI})\end{array}$ & $\begin{array}{l}\text { Düzeltilmiş } \\
\text { İyi Uyum } \\
\text { İndeksi } \\
\text { (AGFI) }\end{array}$ & $\begin{array}{l}\text { Normlaştırılmış } \\
\text { Uyum İndeksi } \\
\text { (NFI) }\end{array}$ & $\begin{array}{l}\text { Karşılaş̧tırmalı } \\
\text { Uyum İndeksi } \\
\text { (CFI) }\end{array}$ & $\begin{array}{c}\text { Yaklaşık } \\
\text { Hataların } \\
\text { Ortalama } \\
\text { Karekökü } \\
\text { (RMSEA) }\end{array}$ \\
\hline Model 1 & $92,155^{* * *}$ & 1 & 92,155 & 0,807 & $-0,159$ & 0,078 & 0,059 & 0,535 \\
\hline Model 2 & $70,334 * * *$ & 1 & 70,334 & 0,853 & 0,115 & 0,296 & 0,284 & 0,467 \\
\hline Model 3 & $59,354 * * *$ & 1 & 59,354 & 0,876 & 0,253 & 0,406 & 0,398 & 0,428 \\
\hline Model 4 & $58,189 * * *$ & 1 & 58,189 & 0,878 & 0,268 & 0,418 & 0,410 & 0,424 \\
\hline Model 5 & $20,754 * * *$ & 1 & 20,754 & 0,956 & 0,739 & 0,792 & 0,796 & 0,249 \\
\hline Model 6 & $20,246^{* * *}$ & 1 & 20,246 & 0,958 & 0,745 & 0,797 & 0,801 & 0,246 \\
\hline Model 7 & $18,375^{* * *}$ & 1 & 18,375 & 0,961 & 0,769 & 0,816 & 0,821 & 0,234 \\
\hline
\end{tabular}

Çalışmada değerlendirilen yedi farklı modelin uyum iyiliği gösterge değerleri açısından sıralanarak birbirleriyle kıyaslanmaları sağlanmıştır. Bir modelin değerlendirilmesinde uyum iyiliği gösterge değerlerinin katı bir şekilde sınırlandırılmaması gerektiği (Hu ve Bentler, 1998) ve uyum iyiliğinin doğru değerlendirilmesi için farklı uyum gösterge değerlerinin alınması gerektiği belirtildiğinden (Hayduk ve ark., 2007) dolayı farklı modellerin kıyaslanması kısmen öznel olmaktadır. Ancak burada uyum gösterge değerleri kıyaslamayı kolaylaştırmak için sıralanarak verilmiştir.

\section{TARTIŞMA, SONUÇ, ÖNERİLER}

Duygusal zeka, empati ve sosyal beceri ile ilgili çalışmalarda olgular arası ilişkiler pek çok çalışmada gözlenirken, olgulardan birisindeki yükselişin nasıl diğer olgulardan birindeki yükselişe (ya da düşüşe) bağl1 olduğu ortaya konulmaktadır (Castillo ve ark., 2013; Mayer ve ark., 1999; Schutte ve ark., 2001). Ancak bu üç olgunun birlikte ele alınmasıyla ortaya konulacak ilişkisel yapının bu belirtilenlerden daha fazla bilgi sağlayabileceği düşünülmektedir. Özellikle her üç olgunun da yaşa bağlı olarak değişim gösterdiği dikkate alındığında (Adams, 1983; Adams ve ark., 1979; Cabello ve ark., 2016; Denton ve Zarbatany, 1996; Flynn ve ark., 2019; Mayer ve ark., 2016; Richter ve Kunzmann, 2011; Wieck ve Kunzmann, 2015; Zhaoyang ve ark., 2018) ve farklı yaş gruplarına ilişkin karşılaştırma yapmak için gerekli olan katılımcı sayısının fazlalığı ile ortaya çıkan zorluk göz önünde bulundurulduğunda uygulama grubu olarak sadece bir yaş grubunun alınması (genç yetişkinler) çalışma açısından daha pratik bulunmuştur. Bu çalışmada bu doğrultuda genç yetişkinlerde yol analiziyle bu üç olgusal yapı arası farklı ilişkisel modellerin test edilmesi düşünülmüştür. Bu doğrultuda çalışmada, duygusal zeka, empati ve sosyal beceri arasındaki ilişkinin görgül veriler kullanılarak yol analiziyle incelenmesi işlemleri yürütülmüştür.

Bu çalışmada ölçme araçlarının özellikleri ve uygulama pratikleri düşünüldügünde insan gelişiminin evreleri de hedef grup olarak dikkate alındığında, genç yetişkinlerin, orta yaşlıların ve yaşlıların oluşturduğu yaş gruplarından birinin, diğerinin ya da bu grupların değişik kombinasyonlarla birlikte alındığı grupların uygulamaya dahil edilmesi mümkün olmaktadır. Yaşın ise incelenen olgular açısından belirleyici özellik taşımasından kaynaklanan öneminden dolayı kritik rolü bulun- 
maktadır. Bu nedenle bu araştırmada, gelişim evrelerinden biri olarak bir yaş grubunun alınması yöntemiyle bir anlamda yaş değişkeninin sabit tutulması yolu izlenmiş olmaktadır. Bu doğrultuda da elde edilen sonuçlar, sadece genç yetişkinlerle sinırlı ve bu yaş gurubu için geçerli olmak koşuluyla değerlendirilmiştir.

Duygusal bilgi işleme süreçlerini ön plana çıkaran çok boyutlu sosyal beceri yaklaşımında, duygusal alanların bilişsel boyutu üzerinde durulmaktadır. Duygusal duyarlılık, sözel olmayan iletişim becerilerindendir ve çevreye karşı duyarlı olmayı, duygusal mesajları çözümleyebilmeyi, empati kurabilmeyi gerektirmektedir. Duygusal dışavurum, kişinin kendi duygularını algılayabilmesini ve duygusal bilgileri duruma uygun bir şekilde ifade etmesini gerektirmektedir (Friedman ve Riggio, 1981). Duygusal denetim ise duygusal uyaranlar karşısında duyguları kontrol etme ve davranışı yönetme becerisidir. Sosyal dişavurum, kişilerarası iletişimde kendini sözel ve sosyal olarak ifade etme ile ilişkilidir. Sosyal duyarlılık ise sosyal normların farkında olma, davranışı bu normlara göre düzenleme, çevrenin sözel ve sözel olmayan mesajlarını yorumlayabilme ve başkalarının duygu ve davranıslarına dikkat etme becerisidir. Sosyal denetim ve sosyal manipülasyon becerileri de kissinin kendini ve başkalarını sosyal ortamda kontrol edebilmesi ve yönlendirmesi ile ilişkilidir. Çok boyutlu bu sosyal beceri yaklaşımda empatinin ve duygusal zekanın önemi açıkça görülmektedir.

Duyguları kavrama ve kullanmadaki bireysel farklılıklar, duygu ve zeka birlikteliğini öne ç1karmıştır. Duygusal zekanın popüler ve akademik yayınlarda pek çok farklı tanımı bulunmaktadır. Bu tanımların birine göre duygusal zeka, duyguları hissetme, düşünceyi desteklemek üzere duygu üretme, duygusal bilgiyi anlama ve duygusal gelişime katkıda bulunmak için duyguları etkin bir şekilde yönetme becerisi olarak kavramsallaştırılmaktadır (Salovey ve Mayer, 1990). Duygusal zekaya yetenek modeli yaklaşımı, duygusal bilgi işleme süreçlerine odaklanarak duygusal zekayı a) duyguları tanımlama (identifying emotions), b) duyguları kullanma (using emotions), c) duyguları anlama (understanding emotions) ve d) duyguları yönetme (managing emotions) olmak üzere dört kategoride incelemektedir (Mayer ve ark., 2016). Bunlardan ilki olan "duyguları tanımlama”, yüz ifadeleri, sesler, resimler ve kültürel ürünlerdeki duyguları saptama ve doğru bir şekilde ifade etme, mevcut ipuçlarını göz önünde bulundurarak gerçek ile sahte duyguları ayırt edebilme becerisidir. İkinci kategori olan "duyguları kullanma”, dikkati önemli olaylara odaklayabilme, mantıklı düşünme ile karar verme sürecini kolaylaştırmak için duruma uygun duygular üretebilme ve çalkantılı ruh halini farklı bakış açıları kazanabilmek için bir firsat olarak görme becerisidir. Üçüncü beceri olan "duyguları anlama”, kompleks duyguları ve duygu dizilerini, duyguların bir evreden diğerine nasıl geçtiğini, nelerin söz konusu duygulara yol açtığını, duygular arasında nasıl bir ilişki olduğunu anlama ile ilgilidir. Sonuncu beceri olan "duyguları yönetme” ise, kişinin kendisinin ve başkalarının duygularına yönelik farkındalığını sürdürebilme, kendi duygularını yönetebilme, negatif duyguları baskılama zorunluluğu hissetmeksizin duyguların yol açtığı problemleri çözebilmeyi ifade etmektedir (Caruso, Mayer ve Salovey, 2002; Mayer ve ark., 2016; Salovey ve Grewal, 2005). Duygusal zekaya ilişkin bu yaklaşımda ise empati ve sosyal becerinin rolü görülmektedir.

Duygusal zeka, empati ve sosyal beceri ile ilgili çalışmalar göz önünde bulundurularak değişkenlerin ikili ikili olarak veya üçünün birlikte ele alındığ1 değişik ilişkisel yapıların test edilmesine yönelik modeller oluşturulmuş ve bunlara ilişkin uyum iyiliği gösterge değerleri hesaplanarak so- 
Ekim 2020, Cilt 2, Sayı 3

October 2020, Volume 2, Issue 3
İletișim / Contact

Mail : info@humanisticperspective.com Web : https://dergipark.org.tr/tr/pub/hp

nuçlarda verilmiştir. Yol analizi ile test edilen modellerin tümü, üç olgunun yukarıda belirtilen ilişkilerine odaklıdır. Diğer bir ifadeyle bu çalışmada alınan olgular arası ilişkilerin farklı şekillerinin test edilmesi amaçlanmıştır. Olguların hangisinin diğerinin öncülü veya sonucu olduğuna ilişkin ilişkileri yansıtan modellerin her birinde uyum iyiliği gösterge değerleri açısından farklılıklar tespit edilmiştir. Katılımcı sayısı, ilişkilerin doğrusal olup olmaması gibi uyum iyiliği gösterge değerlerini etkileyen faktörlerin dışarıda tutulması koşuluyla incelen tüm modeller farklı uyum gösterge değerleri açısından kabaca düşük uyumdan yüksek uyuma doğru sıralandığında en iyi uyum gösterge değerini Model 7’nin verdiği görülmüştür. Sosyal beceri ile duygusal zeka arasındaki ilişkide empatinin aracı rolü taşıdığının belirtildiği (Riggio, 1986) bu model iyi uyum gösterge değerleri sunmasa da incelenen modeller içerisinde en iyi uyum gösterge değerleri veren model olarak yer almıştır.

Elde edilen sonuç(lar) iki önemli ayrıntı içermektedir. Birincisi empatinin işlevsel olarak, sosyal beceri ile duygusal zeka arasında yer alması daha uygun görünmektedir. İkincisi ise bu üç olgu arası ilişkisel yapı sadece bu üç olgunun yer aldığı modellerle yeterli düzeyde ortaya konulamamakta, ilişkilere dahil edilmesine ihtiyaç duyulan başka değişkenlerin olması gerektiği anlaşılmaktadır. Sosyal beceri uzun vadede, yaşam kalitesinin ve sosyal statünün yordayıcıları olan akademik başarıya, iş başarısına, olumlu akran ilişkilerine ve / veya aile uyumuna katkıda bulunmaktadır (DeRosier, 2004). Duygusal zekaya ilişkin beceri yaklaşımında yaşın duygusal zeka düzeyini yordadığı belirtilmektedir (Cabello ve ark., 2016; Mayer ve ark., 2016). Bu ve benzeri çalışma bulgularının dikkate alınarak duygusal zeka, empati ve sosyal beceri ile ilgili ilişkisel yapıların genişletilerek incelenmesinin daha uygun olduğu elde edilen uyum gösterge değerlerinin yetersizliğinden anlaşılmaktadır. Özetle bu çalışmada incelenen olguların ele alındığı çalışmalarda, ilgili değişkenlerin çokluğunun ve etkilerinin, araştırma yöntemleri açısından taşıdığı önemin ötesinde dikkate alınması gerektiği görülmektedir. Ayrıca bu olgular arası neden-sonuç ilişkilerinin kurulmasında, ilgili önceki çalışma sonuçlarının göz önünde bulundurulmasının zorunlu gerekliliği anlaşılmaktadır.

Bu çalışmaya sadece genç yetişkin grubunun alınmış ve farklı yaş grupları için incelenen modellerin test edilmesinin tekrarlanmamış olması ve özellikle sosyal beceri (Adams, 1983; Denton ve Zarbatany, 1996; Flynn ve ark., 2019; Zhaoyang, Sliwinski, Martire ve Smyth, 2018), empati (Adams ve ark., 1979; Richter ve Kunzmann, 2011; Wieck ve Kunzmann, 2015), duygusal zeka (Cabello ve ark., 2016; Mayer ve ark., 2016) gibi yaşa duyarlı olguların incelenmesi nedeniyle, elde edilen sonuçların yaşa yönelik genellenmesi sorununu ortaya çıkarmaktadır. Bu sınırlılık aynı zamanda yeni çalışma önerileri içinde yön gösterici nitelik taşımaktadır. İncelenen olgulara ilişkin yaş ve cinsiyet farklılıklarının önemli çalışma konuları olduğu düşünüldüğünde (Grühn, Sharifian ve Chu, 2016; Mestre, Samper, Frías ve Tur, 2009; Tsaousis ve Kazi, 2013) farklı yaş ve cinsiyet gruplarında bu olgulara ilişkin gizli ya da açık olarak gözlenebilecek puan ortalamaları arası farklılıkların incelenmesinin ilgili bulguları genişleteceği düşünülmektedir.

\section{KAYNAKÇA}

Adams, G. R. (1983). Social competence during adolescence: social sensitivity, locus of control, empathy, and peer popularity. Journal of Youth and Adolescence, 12(3), 203-211. 
Adams, G. R., Schvaneveldt, J. D. \& Jensen, G. O. (1979). Sex, age and perceived competency as correlates of empathic ability in adolescence. Adolescence, 14(56), 811-818.

Baron-Cohen, S. \& Wheelwright, S. (2004). The empathy quotient: an investigation of adults with asperger syndrome or high functioning autism and normal sex differences. Journal of Autism and Developmental Disorders, 34(2), 163-175.

Bora, E. ve Baysan,L. (2009). Empati Ölçeği-Türkçe formunun üniversite öğrencilerinde psikometrik özellikleri. Klinik Psikofarmakoloji Bülteni, 19(1), 39-47.

Cabello, R., Sorrel, M. A., Fernández-Pinto, I., Extremera, N. \& Fernández-Berrocal, P. (2016). Age and gender differences in ability emotional intelligence in adults: a cross-sectional study. Developmental Psychology, 52(9), 1486-1492.

Caruso, D. R., Mayer, J. D. \& Salovey, P. (2002). Relation of an ability measure of emotional intelligence to personality. Journal of Personality Assessment, 79(2), 306-320.

Castillo, R., Salguero, J. M., Fernández-Berrocal, P. \& Balluerka, N. (2013). Effects of an emotional intelligence intervention on aggression and empathy among adolescents. Journal of Adolescence, 36(5), 883-892.

Clarke, M. J., Marks, A. D. \& Lykins, A. D. (2016). Bridging the gap: the effect of gender normativity on differences in empathy and emotional intelligence. Journal of Gender Studies, 25(5), 522-539.

Davis, M. H. (1983). Measuring individual differences in empathy: evidence for a multidimensional approach. Journal of Personality and Social Psychology, 44(1), 113-126.

Denton, K. \& Zarbatany, L. (1996). Age differences in support processes in conversations between friends. Child Development, 67(4), 1360-1373.

Flynn, R. M., Ricker, A. A., Dolezal, C., Kunin, M. \& Mellins, C. A. (2019). Residential summer camp for youth with special needs: a longitudinal approach to investigating differences in social skills. Children and Youth Services Review, 96, 354-363.

Friedman, H. S. \& Riggio, R. E. (1981). Effect of individual differences in nonverbal expressiveness on transmission of emotion. Journal of Nonverbal Behavior, 6(2), 96-104.

Garaigordobil, M. \& Peña, A. (2014). Intervención en las habilidades sociales: efectos en la inteligencia emocional y la conducta social. Psicología Conductual, 22(3), 551-567.

Grühn, D., Sharifian, N. \& Chu, Q. (2016). The limits of a limited future time perspective in ex- 
plaining age differences in emotional functioning. Psychology and Aging, 31(6), 583-593.

Hayduk, L., Cummings, G., Boadu, K., Pazderka-Robinson, H. \& Boulianne, S. (2007). Testing! testing! one, two, three-Testing the theory in structural equation models!. Personality and Individual Differences, 42(5), 841-850.

Hu, L. T. \& Bentler, P. M. (1998). Fit indices in covariance structure modeling: Sensitivity to underparameterized model misspecification. Psychological Methods, 3(4), 424-453.

Ishak, N. M., Abidin, M. H. Z. \& Bakar, A. Y. A. (2014). Dimensions of social skills and their relationship with empathy among gifted and talented students in Malaysia. Procedia-Social and Behavioral Sciences, 116, 750-753.

Kaelber, K. A. \& Schwartz, R. C. (2014). Empathy and emotional intelligence among eastern and western counsellor trainees: a preliminary study. International Journal for the Advancement of Counselling, 36(3), 274-286.

Khodabakhsh, M. R. \& Besharat, M. A. (2011). Mediation effect of narcissism on the relationship between emotional intelligence and the quality of interpersonal relationships. Procedia-Social and Behavioral Sciences, 30, 907-911.

Lawrence, E. J., Shaw, P., Baker, D., Baron-Cohen, S. \& David, A. S. (2004). Measuring empathy: reliability and validity of the empathy quotient. Psychological Medicine, 34(5), 911-920.

Lopes, P. N., Brackett, M. A., Nezlek, J. B., Schütz, A., Sellin, I. \& Salovey, P. (2004). Emotional intelligence and social interaction. Personality and Social Psychology Bulletin, 30(8), 1018-1034.

Mayer, J. D. \& Salovey, P. (1997). What is emotional intelligence? In P. Salovey, \& D. J. Sluyter (Eds.), Emotional development and emotional intelligence: educational implications (pp. 3-34). New York: Harper Collins.

Mayer, J. D., Caruso, D. R. \& Salovey, P. (1999). Emotional intelligence meets traditional standards for an intelligence. Intelligence, 27(4), 267-298.

Mayer, J. D., Caruso, D. R. \& Salovey, P. (2016). The ability model of emotional intelligence: principles and updates. Emotion Review, 8(4), 290-300.

Mayer, J. D., Salovey, P. \& Caruso, D. R. (2008). Emotional intelligence: new ability or eclectic traits? American Psychologist, 63(6), 503-517.

Mestre, M. V., Samper, P., Frías, M. D. \& Tur, A. M. (2009). Are women more empathetic than men? A longitudinal study in adolescence. The Spanish Journal of Psychology, 12(1), 76-83. 
Muncer, S. J. \& Ling, J. (2006). Psychometric analysis of the Empathy Quotient (EQ) Scale. Personality and Individual Differences, 40(6), 1111-1119.

Mustaffa, S., Nasir, Z., Aziz, R. \& Mahmood, M. N. (2013). Emotional intelligence, skills competency and personal development among counseling teachers. Procedia-Social and Behavioral Sciences, 93, 2219-2223.

Petrovici, A. \& Dobrescu, T. (2014). The role of emotional intelligence in building interpersonal communication skills. Procedia-Social and Behavioral Sciences, 116, 1405-1410.

Richter, D. \& Kunzmann, U. (2011). Age differences in three facets of empathy: performancebased evidence. Psychology and Aging, 26(1), 60-70.

Riggio, R. E. (1986). Assessment of basic social skills. Journal of Personality and Social Psychology, 51(3), 649-660.

Riggio, R. E., Tucker, J. \& Coffaro, D. (1989). Social skills and empathy. Personality and Individual Differences, 10(1), 93-99.

Salovey, P. \& Grewal, D. (2005). The science of emotional intelligence. Current Directions in Psychological Science, 14(6), 281-285.

Salovey, P. \& Mayer, J. D. (1990). Emotional intelligence. Imagination, Cognition and Personality, 9(3), 185-211.

Schutte, N. S., Malouff, J. M., Bobik, C., Coston, T. D., Greeson, C., Jedlicka, C., ...Wendorf, G. (2001). Emotional intelligence and interpersonal relations. The Journal of Social Psychology, 141(4), 523-536.

Schutte, N. S., Malouff, J. M., Hall, L. E., Haggerty, D. J., Cooper, J. T., Golden, C. J., Dornheim, L. (1998). Development and validation of a measure of emotional intelligence. Personality and Individual Differences, 25(2), 167-177.

Shaffer, D. R. \& Kipp, K. (2010). Developmental psychology: childhood and adolescence (8. ed.). Belmont, CA: Wadsworth, Cengage Learning.

Sharma, S., Deller, J., Biswal, R. \& Mandal, M. K. (2009). Emotional intelligence: factorial structure and construct validity across cultures. International Journal of Cross Cultural Management, 9(2), 217-236.

Stanley, S. \& Bhuvaneswari, G. M. (2016). Reflective ability, empathy, and emotional intelligence in undergraduate social work students: a cross-sectional study from India. Social Work Educa- 
tion, 35(5), 560-575.

Tatar, A., Özdemir, H., Haşlak, F. D., Atsızelti, Ş., Özüdoğru, M. T., Çavuşoğlu, F., Çelikbaş, B., Uysal, A. R., Toklu, N., Uyğur, G., Astar, M. ve Saltukoğlu, G. (2018). Yetişkinler için A Sosyal Beceri Ölçeği’nin geliştirilmesi ve psikometrik özelliklerinin incelenmesi. Akademik Sosyal Araștirmalar Dergisi, 6(68), 69-88.

Tatar, A., Saltukoğlu, G., Tok, S. ve Bender, M. T. (2016). UKMH Duygusal Zeka Testinin Türkçeye uyarlanması ve psikometrik özelliklerinin incelenmesi. Anadolu Psikiyatri Dergisi, 17(1), 5-13.

Tatar, A., Tok, S., Bender, M. T. ve Saltukoğlu, G. (2017). Asıl Form Schutte Duygusal Zeka Testinin Türkçeye çevirisi ve psikometrik özelliklerinin incelenmesi. Anadolu Psikizatri Dergisi, 18(2), 139-146.

Tsaousis, I. \& Kazi, S. (2013). Factorial invariance and latent mean differences of scores on trait emotional intelligence across gender and age. Personality and Individual Differences, 54(2), 169173.

Wieck, C. \& Kunzmann, U. (2015). Age differences in empathy: multidirectional and context-dependent. Psychology and Aging, 30(2), 407-419.

Yip, J. A. \& Martin, R. A. (2006). Sense of humor, emotional intelligence, and social competence. Journal of Research in Personality, 40(6), 1202-1208.

Zhaoyang, R., Sliwinski, M. J., Martire, L. M. \& Smyth, J. M. (2018). Age differences in adults' daily social interactions: an ecological momentary assessment study. Psychology and Aging, 33(4), 607-618.

Zorza, J. P., Marino, J., de Lemus, S. \& Mesas, A. A. (2013). Academic performance and social competence of adolescents: predictions based on effortful control and empathy. The Spanish Journal of Psychology, 16, 1-12. 